\title{
District of Columbia, DC
}

National Cancer Institute

\section{Source}

National Cancer Institute. District of Columbia, DC. NCI Thesaurus. Code C108007.

The area in the United States comprised of a 68 square mile area northeast of the Potomac River donated by the state of Maryland. The District of Columbia, also known as D.C., is not a state, nor is it part of any state. It is a "federal district" established by the US Constitution as the seat of government. The district is occupied entirely by the city of Washington. 